\title{
The Evolution of Smart Wrist Band by Using Sensors
}

\author{
Mangalam R. Srikrishnan*, \\ Naganathan Archana and Joy Niresh \\ PSG College of Technology \\ Coimbatore, India
}

Received 14.03.2020, received in revised form 22.04.2020, accepted 21.05.2020

\begin{abstract}
In recent years, the integration of various electronic components and sensors with textiles aimed at giving additional functions has become more common. In this respect the wrist band can be made functional while retaining the aesthetic appeal and style at lower cost which is in high demand. Smart textiles are fabrics that have been designed and manufactured to include technologies that provide the wearer with increased functionality. Smart textiles can be produced by knitting, weaving and embroidering with conductive threads, conductive metal coating and screen printing that can be used to develop wearable electronic textiles but amongst these, the use of conductive inks onto textiles has gained interest due to the ease of their use and manufacturing scalability. The emergence of wireless technologies and advancement in on-body sensor design can enable change in the conventional healthcare system, replacing it with wearable ones, centered on the individual. Wearable monitoring systems can provide continuous physiological data, as well as better information regarding the general health of individuals. Thus, such vital-sign monitoring systems will reduce healthcare costs by disease prevention and enhance the quality of life. This dissertation is aimed at developing smart band by incorporating vital-sign monitoring systems. Using this assembly, the recent progress in non-invasive monitoring technologies for chronic disease management is reviewed. Devices and techniques for monitoring pulse rate and body temperatures are discussed in particular. For our research conductive ink and conductive fabrics are presented additionally. The main aim of this project is to produce a wearable wrist band which detects vital body parameters like pulse rate and temperature using sensors, conductive ink and conductive fabric. Finally, the recorded temperature and pulse rate readings are sent to mobile app via Wi-Fi.
\end{abstract}

Keywords: wrist band, healthcare, pulse rate.

Citation: Srikrishnan M.R., Archana N., Niresh J. The evolution of smart wrist band by using sensors, J. Sib. Fed. Univ. Eng. \& Technol., 2020, 13(5), 525-535. DOI: 10.17516/1999-494X-0244

(C) Siberian Federal University. All rights reserved

This work is licensed under a Creative Commons Attribution-Non Commercial 4.0 International License (CC BY-NC 4.0).

* Corresponding author E-mail address: krkrishnapsg32@gmail.com 


\title{
Усовершенствование смарт-браслета
}

\section{с помощью датчиков}

\author{
М.Р. Шрикришнан, Н. Арчана, Дж. Ниреш \\ Политехнический институт \\ Индия, Коимбатур
}

Аннотация. В последние годы, чтобы реализовать дополнительные функции, стала более распространенной интеграция различных электронных компонентов и датчиков с текстилем. Благодаря этому браслет может быть функциональным, оставаясь при этом эстетически привлекательным и стильным при низкой стоимости, что пользуется большим спросом. Интеллектуальный текстиль - это ткани, которые были разработаны и изготовлены с учетом технологий, обеспечивающих владельца повышенной функциональностью. Интеллектуальный текстиль может быть получен путем вязания, плетения и вышивки электронитями, металлическим покрытием и трафаретной печатью, которая может быть использована для разработки носимых электронных текстильных изделий, но среди существующих технологий применение проводящих чернил на текстиле привлекло интерес из-за простоты использования и масштабируемости производства. Появление беспроводных технологий и прогресс в разработке датчиков, которые можно носить на теле человека, способны изменить традиционную систему, позволяющую следить за состоянием здоровья человека, и заменить ее мобильными системами, ориентированными на индивидуальный организм. Носимые системы слежения могут предоставлять непрерывные физиологические данные, а также болееподробную информацию об общем состоянии здоровья человека. Таким образом, системы отслеживания жизненно важных показателей позволят сократить расходы на медицинское обслуживание за счет предотвращения развития заболеваний и повысить качество жизни. Целью этой работы является разработка смарт-браслета с системами отслеживания жизненно важных показателей. С помощью такого устройства был пересмотрен недавний прогресс в области неинвазивных технологий мониторинга лечения хронических заболеваний. В частности, обсуждаются приборы и методы контроля частоты пульса и температуры тела. Для нашего исследования дополнительно представлены проводящие чернила и проводящие ткани. Основной целью этого проекта является создание мобильного браслета, который определяет жизненно важные параметры тела, такие как частота пульса и температура, с помощью датчиков, проводящих чернил и проводящей ткани. Наконец, записанные показания температуры и частоты пульса отправляются в мобильное приложение через Wi-Fi.

Ключевые слова: браслет, здравоохранение, частота пульса.

Цитирование: Шрикришнан, М.Р. Усовершенствование смарт-браслета с помощью датчиков / М.Р. Шрикришнан, Н. Арчана, Дж. Ниреш // Журн. Сиб. федер. ун-та. Техника и технологии, 2020. 13(5). С. 525-535. DOI: 10.17516/1999494X-0244

\section{Introduction}

Smart textiles are fabrics that have been designed and manufactured to include technologies that provide the wearer with increased functionality. Smart textiles can be produced by knitting, weaving and embroidering with conductive threads, conductive metal coating and screen printing that can be used to develop wearable electronic textiles but amongst these, the use of conductive inks onto textiles has gained interest due to their ease of use and manufacturing scalability. Heart rate, also known as pulse, is the number of times a person's heart beats per minute. However, a normal heart rate depends on the individual, age, body size, heart conditions, whether the person 
sits or moves, medicine use and even air temperature. Emotions can affect heart rate; for example, getting excited or scared can increase the heart rate. Resting heart rate is your pulse when you sit calmly or lie. It is better to measure your resting heart rate in the morning before you get out of bed, according to the AHA. A healthy body temperature is maintained by the nervous system. As the body temperature increases, the body tries to maintain its normal temperature by transferring heat. Sweating and blood flow to the skin (thermoregulation) help us keep our bodies cool. A heat-related illness occurs when our bodies can no longer transfer enough heat to keep us cool. A high body temperature (hyperthermia) can develop rapidly in extremely hot environments. People's normal body temperatures may vary and are affected by factors such as eating, exercising, sleeping, and what time of the day it is. Our body temperature is usually at its highest at around 6 p.m. and at its lowest at about 3 a.m. A high body temperature, or fever, is one of the ways our immune system attempts to combat an infection.

\section{Materials and methods}

\subsection{Flow chart}

Sourcing of raw material (conductive yarns and conductive pen)

\section{$\downarrow$}

Characterization of yarn and sensing material

\section{$\downarrow$}

Development of conductive fabric by weaving

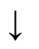

Sensor selection and circuit development

$\downarrow$

Integration of sensor and circuit in wrist band

$\downarrow$

Design and development of mobile application

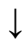

Testing

\subsection{Sourcing of raw material}

In order to develop the textile based on temperature sensor fabric, base textile material, i.e. cotton is selected. We had used the cotton yarn $40^{\mathrm{s}} \mathrm{Ne}$ for warp and weft yarn. Copper metallic wire used as a sensing material is used as warp.

\subsubsection{Characterization of yarn and sensing material wire length vs resistance}

The conductivity of the material was measured in the terms of its resistance. Resistance increases with length because the electron has further to go, so it suffers greater collisions with atoms in the material. The test was performed to measure the resistance value of the sensing material at different lengths using the digital multi meter device. AATCC test method $84-2000$ was used to measure the wire resistance. Resistance of a conductor is directly proportional to its length and inversely proportional to the thickness, i.e. if thickness increases the resistance decreases. Value Noted - $(0.3-$ $0.5 \Omega$ ) while changing its length. 


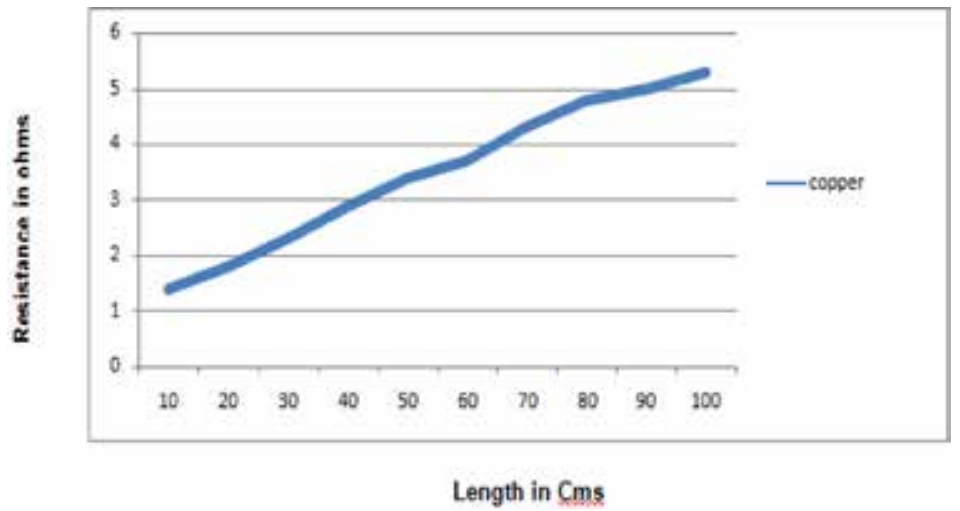

Fig. 1. Wire length vs resistance

\section{TIME VS TEMPERATURE}

In developed fabric we have checked the relation between time and temperature, when electrical power is supplied to the material, metallic compound receives heat, so temperature will increase. It creates error while measuring the temperature, so we analyzed the temperature change at particular time. $9 \mathrm{v}$ battery power is supplied to the temperature sensing fabric, the changes in temperature and the resistance value was measured.

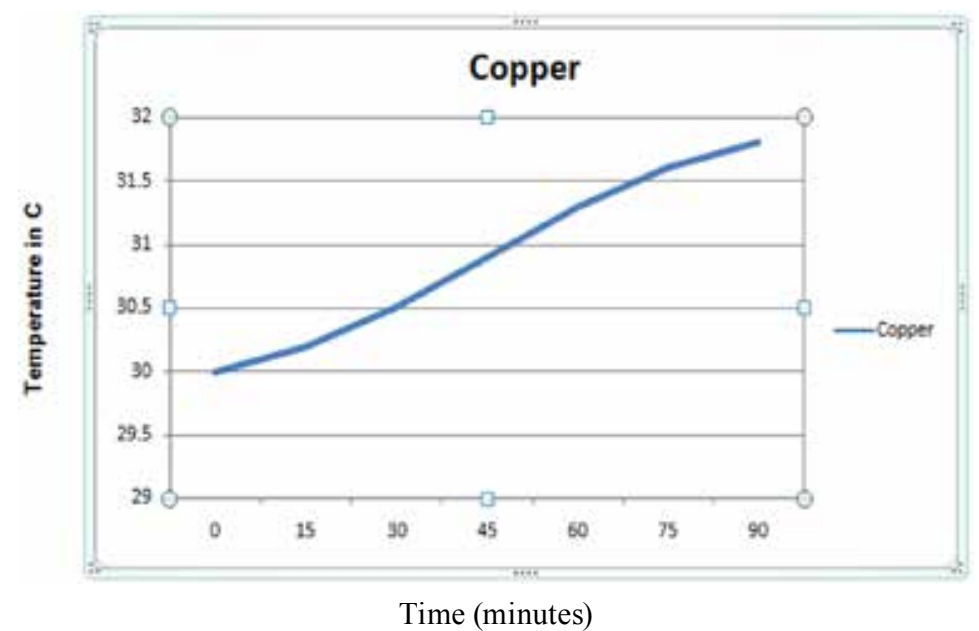

Fig. 2. Time vs Temperature

\section{TIME VS RESISTANCE}

Important parameter of temperature sensing fabric is changes of resistance in variable temperature, this resistance changes due to the variation of electron movement at different temperatures. The samples placed in a hot plate and the resistance value is measured by digital multimeter at different temperature values, based on this result we decide the temperature range of the temperature sensing fabric. 


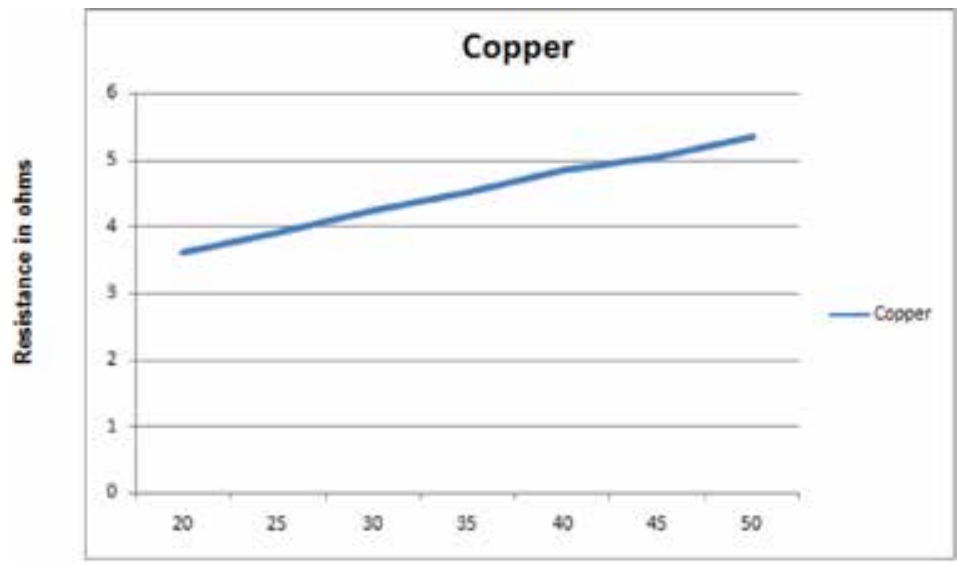

Time (minutes)

Fig. 3. Time vs Resistance

\subsubsection{Development of conductive fabric by weaving}

The conductive fabric has been developed by using conductive yarns(copper) in the warp direction, which has the diameter of $0.3 \mathrm{~mm}$. Plain weave is chosen to develop the fabric.

\subsubsection{Sensor selection and circuit development}

The circuit was developed by using heart beat sensor and temperature sensor, arduino micro controller, HC- 05 Bluetooth module.

\section{A temperature measuring unit}

Temperature sensor is a device which gives temperature measurement as an electrical signal and is called a temperature sensor. This electrical signal will be in the form of electrical voltage and is proportional to the temperature measurement. Reason for using LM35 is that it accurately measures the temperature in comparison to thermistor and it is not subjected to oxidation as the sensor circuitry is sealed. Besides, the output voltage of LM35 does not need to be amplified. The low output impedance, linear output and precise inherent calibration of the LM35 make its interfacing to control circuitry very easy.

LM35 is an analog, linear temperature sensor whose output voltage varies linearly with change in temperature. LM35 is three terminal linear temperature sensors from national semiconductors. It can measure temperature from- 55 degree Celsius to +150 degree Celsius. LM 35 can be operated from a $5 \mathrm{~V}$ supply and stand by current that is less than $60 \mathrm{uA}$.

There are two transistors in the center of the drawing. One has ten times the emitter area of the other. This means it has one tenth of the current density, since the same current is going through both transistors. This causes a voltage across the resistor R1 that is proportional to the absolute temperature and is almost linear across the range. The "almost" part is taken care of by a special circuit that straightens out the slightly curved graph of voltage versus temperature. The amplifier at the top ensures that the voltage at the base of the left transistor (Q1) is proportional to absolute temperature (PTAT) by comparing the output of the two transistors.

$$
-529-
$$


Fig. 4. Temperature sensor (LM35)

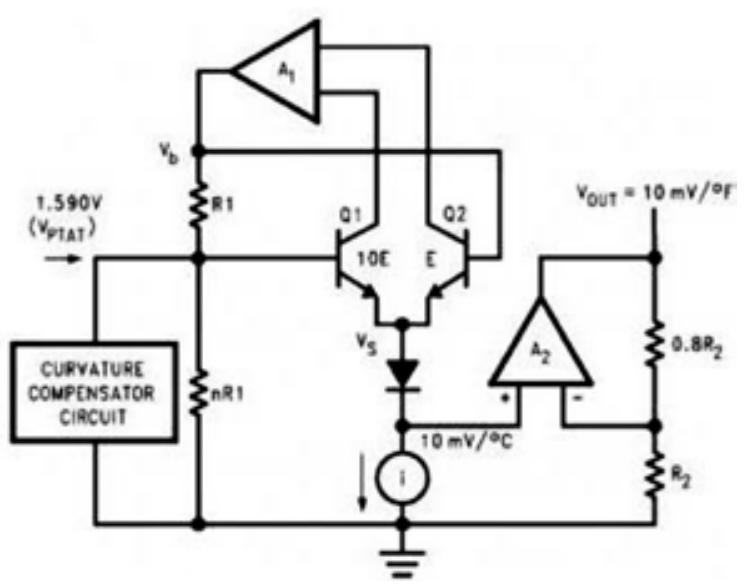

Working of temperature sensor

Fig. 5. Temperature sensor circuit

The amplifier on the right converts absolute temperature (measured in Kelvin) into either Fahrenheit or Celsius, depending on the part (LM34 or LM35). The little circle with the " $\mathrm{i}$ " in is a constant current source circuit. The two resistors are calibrated at the factory to produce a highly accurate temperature sensor. The integrated circuit has many transistors in it -- two in the middle, some in each amplifier, some in the constant current source, and some in the curvature compensation circuit. All of them are fitted into the tiny package with three leads.

With increase in output of $10 \mathrm{mV}$ by the sensor v-out pin the temperature value increases by one. For example, if the sensor outputs 100 mills volt at the pin, the temperature in centigrade will be 10 degree centigrade. The same goes for the negative temperature reading. If the sensor outputs $100 \mathrm{mV}$, the temperature will be 10 degrees Celsius.

\section{A heartbeat measuring unit}

Heartbeat measurement can be based on optical power variation as light is scattered or absorbed during its path through the blood as the heartbeat changes.

\subsection{Principle of a heartbeat sensor}

The heartbeat sensor is based on the principle of photo plethysmography. It measures the change in volume of blood through any organ of the body which causes a change in the light intensity through 


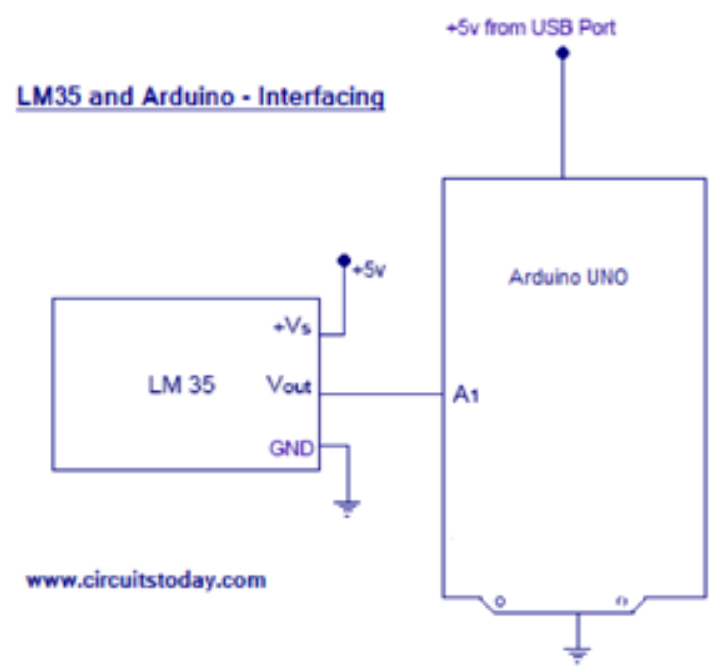

Fig. 6. Connection between arduino and LM35
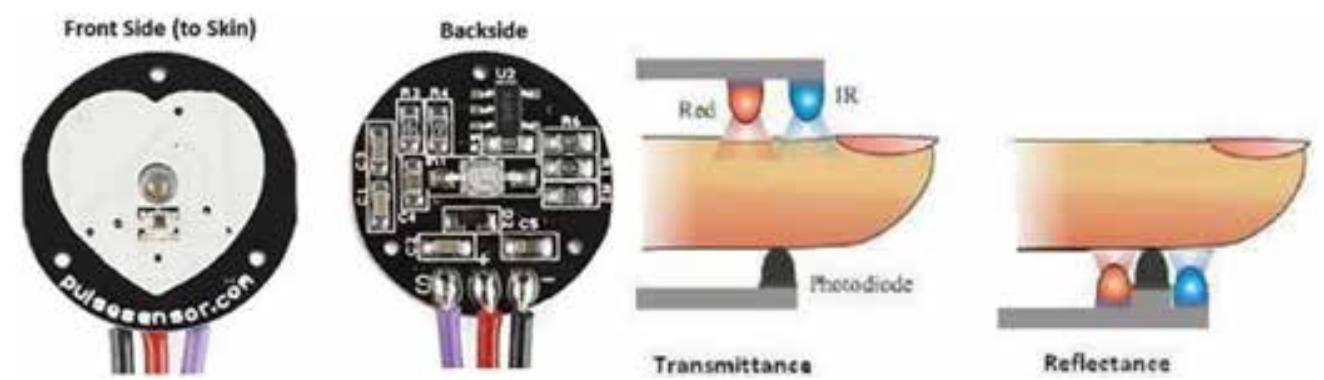

Fig. 7. Heartbeat sensor and its work

that organ (a vascular region). In case of applications where heart pulse rate is to be monitored, the timing of the pulses is more important. The flow of blood volume is decided by the rate of heart pulses and since light is absorbed by blood, the signal pulses are equivalent to the heartbeat pulses.

\subsection{Working of heartbeat sensor}

The basic heartbeat sensor consists of a light emitting diode and a detector like a light detecting resistor or a photodiode. The heartbeat pulses cause a variation in the flow of blood to different regions of the body. When a tissue is illuminated with the light source, i.e. light emitted by the led, it either reflects (a finger tissue) or transmits the light (earlobe). Some of the light is absorbed by the blood and the transmitted or reflected light is received by the light detector. The amount of light absorbed depends on the blood volume in that tissue. The detector output is in the form of electrical signal and is proportional to the heartbeat rate.

This signal is actually a DC signal relating to the tissues and the blood volume and the AC component are synchronous with the heartbeat and are caused by pulsatile changes in arterial blood volume that is superimposed on the DC signal. Thus, the major requirement is to isolate that $\mathrm{AC}$ component as it is of prime importance. 


\section{Arduino microcontroller (nano)}

The Arduino Nano is a small, complete and breadboard-friendly board based on the ATmega328P (Arduino Nano 3.x). It has more or less the same functionality of the Arduino Duemilanove, but in a different package. It lacks only a DC power jack and works with a Mini-B USB cable instead of a standard one.

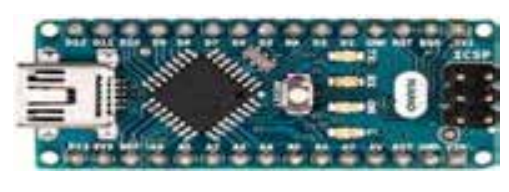

Fig. 8. Arduino nano

The arduino has been programmed by using Arduino software in C programming language.

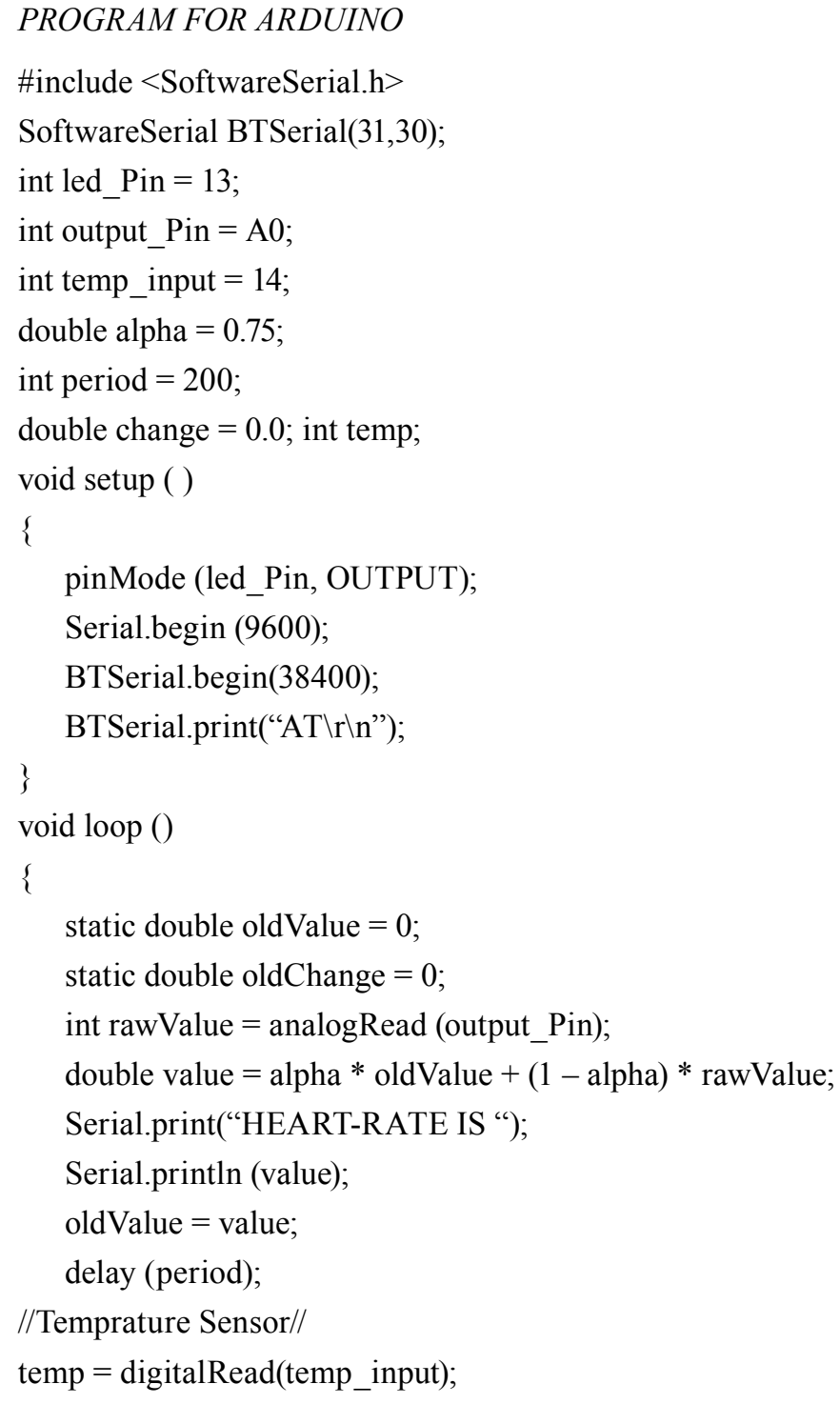




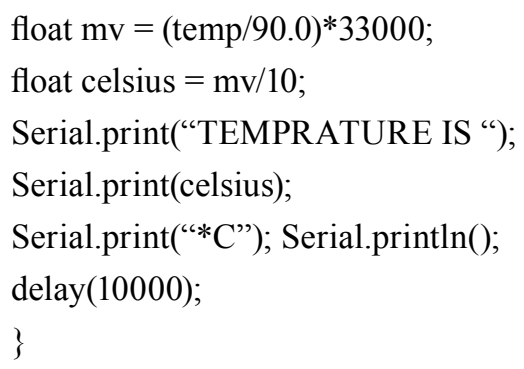

\section{Circuit connections}

The sensors are connected to the microcontroller using conductive fabric and conductive yarns. The connections are made as follows.

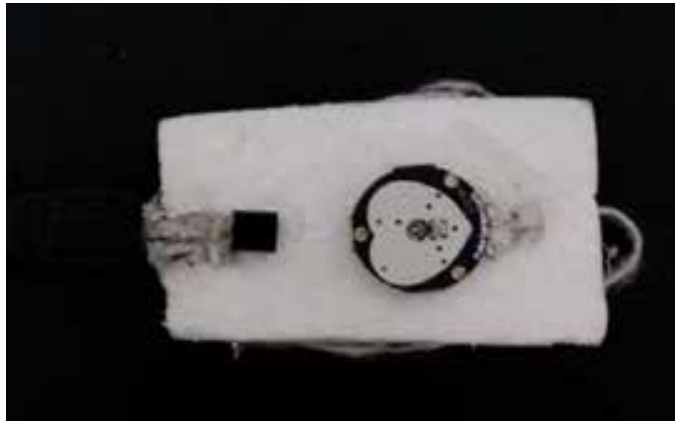

Fig. 9. Circuit connection

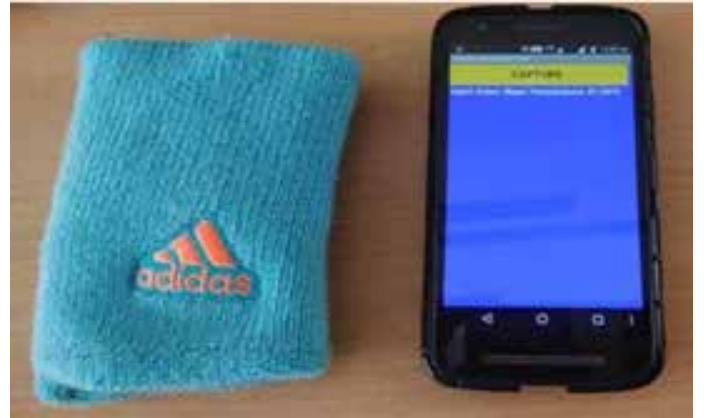

Fig. 10. Smart wrist band and reading

\subsection{App development}

The mobile application to display the readings from heartbeat and temperature has been developed by using MIT app inventor software. This software has design and block window where one can design the layout and, also, customize the application as per requirement.

\section{Results and discussion}

The output from sensor and amplifier circuit was connected to the microcontroller. The observed output signal was periodic ac signal with amplitude varying from peak to peak according to a person. A model sinusoidal signal and the output from sensor were fed to microcontroller and the counted pulse rate was successfully sent via Wi-Fi module.

From the above it is found that the heartbeat may also vary depending upon the activity, emotions, stress and other external factors. Following are the readings based upon the age, activity. It is found that the most active people have less heartbeat rate compared to the less active people. It indicates the efficiency of working of heart.

The temperature was measured for the age group of 21 . The temperature of the body varies in the range of 36 to $36.4{ }^{\circ} \mathrm{C}$ for the age of 19 to 24 . The body temperature also depends on the body part where it is measured. It may be different for different organs. 


\begin{tabular}{|c|c|c|c|}
\hline S.No & Age Group & Pulse rate & $\begin{array}{c}\text { Body } \\
\text { temperature(Celsius) }\end{array}$ \\
\hline 1. & 12 & 82 & 36.0 \\
\hline 2. & 14 & 77 & 36.0 \\
\hline 3. & 16 & 80 & 36.5 \\
\hline 4. & 22 & 72 & 37.4 \\
\hline 5. & 22 & 96 & 37.5 \\
\hline 6. & 31 & 91 & 37.0 \\
\hline 7. & 44 & 98 & 37.0 \\
\hline 8. & 46 & 104 & 36.4 \\
\hline 9. & 52 & 112 & 37.2 \\
\hline 10. & 60 & 110 & 37.0 \\
\hline
\end{tabular}

\section{Conclusion}

This project report discusses the ongoing development of a textile based on a temperature sensor (TSF) and heartbeat sensor that can be integrated into garment, for measuring human body temperature and pulse rate. Copper metallic yarn has been elected as conducting elements for measuring heart rate and temperature as it has least resistance.

The objective of this project was to build a low power, low cost, reliable, non-intrusive, and noninvasive monitoring system that would accurately measure the vital signs. A reliable and continuous vital sign monitoring system targeted towards individuals has been successfully built. The resulting system was also low in power and cost, noninvasive, and provided real time monitoring. It is also easy to use and provides accurate measurements. In future, work can be done for miniaturization of this device which will reduce discomfort and make this device more reliable and user-friendly. In this work a description of novel sensors developed to be integrated in wrist band for monitoring vital signs and body gesture/posture has been presented.

As for some recommendations on future work, the fourth vital sign monitor to this system would be added which measures the oxygen level in the blood. This can be achieved through PPG. Since the PPG is already being used to measure blood pressure, it can easily be extended to measure the oxygenation of blood. Adding this last sensing component would make this system a complete vital signs monitor.

\section{References}

[1] Pailes-Friedman R. Smart Textiles for Designers: Inventing the Future of Fabrics. 2nd Edition, 2016.

[2] Muhammed Dawood, Richard Kennon. Preliminary Investigations into the development of textile based Temperature sensor for Healthcare Applications "Fibrers", 2013. [Electronic recourse]Access: www.mdpi.com/journal/fibers (ISSN 2079 - 6439).

[3] Sarah E. Braddock Clarke and Jane Harris. Digital Visions for Fashion and Textiles: Made in Code. 1st Edition, 2012.

[4] Sally Edwards. Heart Rate Monitor Book, 1993.

[5] Locher I., Kirstein T. \& Tr"oster G. Temperature Profile Estimationwith Smart Textiles, 2005. 
[6] Maciej Sibinski, Malgorzata Jakubowska and Marcin Sloma. Sensors. Flexible Temperature Sensors on Fibers, 2010, 10, 7934-7946.

[7] Roy Benson and Declan Connolly. Heart Rate Training, 2011.

[8] Laukhina E., Laukhin V., Lebedev V., Rovira C. and Veciana J. Conductive fabric responding to extremely small temperature changes. Procedia Engineering, 87 (2014), 144-147. [Electronic recourse] - Access: www.sciencedirect.com

[9] Vigneswaran C., Kandhavadivu P. Development of Electromagnetic Shielding Wearable Electronic Textile using Core Conductive Fabrics. International Journal of Science and Engineering Applications, 2013. NCRTAM ISSN - 2319 - 7560.

[10] Narendra V. Bhat, Devender T. Seshadri, Mandar M. Nate, Ajit V. Gore. Development of Conductive Cotton Fabrics for Heating Devices. Journal of Applied Polymer Science, 2006, 102 (5), 4690-4695.

[11] Masoud Latifi, Pedram Payvandy Rehman. Electro-conductive textile yarns, 2010.

[12] Abdul Rehman Akbar, Md. Kamruzzaman, Weilin Xu, Sayyam Gull, Waqas Ahmed, Junaid Khalid. Development of Weft Knitted Heating Pads on V-bed Hand Flat Knitting Machine by Using Conductive Yarns. American Journal of Polymer Science \& Engineering, 2016, 4 (1).

[13] Muthukumar N., Thilagavathi G. Conductive Polymer Coated Textiles for Biosignal Monitoring. International Journal of Textile and Fashion Technology, 2012, 2 (2).

[14] Vlad Dragos Diaconescu, Liliana Vornicu-Albu, Rodica Diaconescu, Isabela Racea, Aurelia Grigoriu. Sensors for Smart Textiles. Buletinul AGIR nr. 3/2015.

[15] Šahta I., Baltina N., Truskovska J., Blums J. \& Deksnis E. Selection of conductive yarns for knitting an electrical heating element. HPSM/OPTI, 2014, 137, 91-102.

[16] Ashok Kumar L., Vigneswaran C. Electronics in Textiles and Clothing: Design, Products and Applications, 2015.

[17] Novela Auparay. Room Temperature Seebeck Coefficient Measurement of Metals and Semiconductors, 2013.

[18] Liu Hao, Zhang Yi, Chen Li, Xiaojiu Li, Wang Yuxiu, Gao Yan. Characterization of Flexible Heating Fabric Based on Conductive Filaments. Measurement, 2012, 45 (7), 1855-1865.

[19] Julian T Parer. Handbook of fetal heart rate monitoring, 1983.

[20] Stoppa M., Chiolerio A. Wearable Electronics and Smart Textiles: A Critical Review, 2014, 14(7): 11957-11992.

[21] Chin Leong Lim, Chris Byrne, Jason K W Lee. Human Thermoregulation and Measurement of Body Temperature in Exercise and Clinical Settings. Annals of the Academy of Medicine, Singapore, 2008, 37(4): 347-353. 